Author Posting (C) Westburn Publishers Ltd, 2019. This is a post-peer-review, pre-copy-edit version of an article which has been published in its definitive form in Social Business and has been posted by permission of Westburn Publishers Ltd for personal use, not for redistribution. The article was published in Social Business, Vol. 9, 2019, No. 3, pp.248-271, doi: https://doi.org/10.1362/204440819X15633617555858 


\section{TOWARDS A MODEL OF DONOR BEHAVIOUR RELATING TO MENTAL DISABILITY CHARITIES}

Roger Bennett, Kingston University London. Email: r.bennett@kingston.ac.uk Rohini Vijaygopal, Open University UK. Email: rohini.vijaygopal@open.ac.uk

\section{Structured Abstract}

\section{Purpose}

This paper extends and develops pre-existing "general" models of donor behaviour in order to create a fresh model useful for charities concerned with mental disability.

\section{Design / methodology / approach}

A comprehensive list of variables with the potential to influence donors' behaviour relating to mental disability charities was assembled and then shortened via a random forest regression. Critical variables emerging from the regression were used to construct and test a model designed to predict donors' willingness to give to a mental disability charity.

\section{Findings}

Certain variables commonly found in general models of giving (e.g., altruism, selfcongruence) plus some variables specific to mental disability (e.g., stigmatic stereotyping, "protest" advertising) significantly affected willingness to donate.

\section{Research limitations / implications}

The study employed random forest regression to identify "important" variables. Alternative approaches might have revealed relevant variables not covered by the present study. Donation intention rather than actual giving was examined. 


\section{Practical implications}

Mental disability charities need to frame their fundraising appeals in particular ways.

"Protest" messages, social norms and self-congruity should be emphasised in campaigns.

\section{Social implications}

Effective fundraising undertaken by the UK's (numerous) mental disability charities will generate the funds necessary for charities of this type to expand and improve their services to beneficiaries.

Originality / value

The research presents a fundraising model specifically relevant to mental disability. It contributes to knowledge vis-à-vis fundraising for unpopular causes and lays down a framework for future research.

Key words. Fundraising, charities, donor behaviour, mental disability, stigma, stereotypes, discrimination. 


\section{Introduction}

The motivations of members of the public to donate to charity have been extensively researched, and several comprehensive models of individual (as opposed to corporate) charity giving behaviour have been constructed (e.g., Bendapudi, Singh \& and Bendapudi, 1996; Sargeant, 1999; Sargeant \& Woodliffe, 2007; Smith \& McSweeney, 2007; Drollinger, 2010; Mainardes, Laurett, Degasperi \& Lasso, 2017; see also the review of Bekkers \& Wiepking, 2011 and Bennett, 2018)). Tests of these models typically generate statistically significant and meaningful results. Unfortunately, however, "general" models of donor behaviour are not necessarily useful for charities that deal with "unpopular" causes, e.g., prisoner rehabilitation, help for immigrant asylum seekers, self-inflicted health conditions. The purpose of the present paper is to create a model that explains donor behaviour relating to a particular genre of unpopular cause: mental disability (see end note 1).

Certain elements of the extant models of donor behaviour are undoubtedly relevant to fundraising for mental disability (altruistic dispositions among donors for instance) but special considerations might affect donors' willingness to give to a mental disability cause (Body, 2015), especially stigma against people with mental disabilities. The stigmatisation of people with mental disabilities is widespread (Batty, 2004; Thornicroft, Rose \& Mehta, 2010), is known to occur across all socio-economic groups (Corrigan, 2000; Davey, 2013; MIND, 2015), and causes people with mental disabilities to be among the most marginalised of all social groups (Pescosolido et al., 1999; Kirkwood \& Stamm, 2006; Sampogna et al., 2017). Even though certain kinds of mental issue do not carry the same stigma as they once did (depression for instance), the stigmatisation of people with mental disabilities persists. For example, 34\% of a sample of members of the public surveyed by MIND (2015) were unwilling to live with an individual who had a mental problem; $20 \%$ did not want to live near 
to a mentally ill person; and $24 \%$ did not wish to work with anyone who was mentally impaired.

Negative stereotypes of people with mental disabilities often include perceptions that they are "dangerous, unpredictable, violent and bizarre", and that mental disability results from "weak morals, poor character, malingering, lack of self-control or bad breeding" (Ross and Goldner, 2009 p.560). Stigmatisation can "motivate the public to fear, reject, avoid and discriminate against people with mental illnesses" (Hogan, 2003 p.4). Views of this nature can lead to assumptions that donations to mental disability charities will be squandered on undeserving people. Body and Breeze (2016) noted how cancer, children's and animal charities dominate the UK's "most popular" charity list, with mental disability receiving scant attention. Their analysis of UK newspaper articles covering unpopular causes ranked mental disability at number one, followed by refugee charities and then by ex-offender charities.

It follows that generic models of donor behaviour are too blunt an instrument to guide mental disability charities when soliciting donations. The pre-existing models take into account too wide a range of variables (typically incorporating numerous personality traits [Brown \& Taylor, 2015]) and do not consider the special circumstances of charities concerned with mental disability (cf. Hibbert \& Horne, 1996). Instead, parsimonious models are needed that identify the specific factors that drive donor behaviour within particular sectors.

\section{Aims and importance of the research}

\section{Aims}

Many members of the public view mental disability more negatively than any other type of impairment (Corrigan et al., 2001). It follows that the behaviour of potential donors to mental disability charities is likely to differ from that of supporters of other kinds of charitable cause 
(Corrigan, 2000). Hence, it is necessary to identify the key variables that are specifically relevant to the public's willingness to give to mental disability charities. Accordingly, the aims of the present study were:

1. To collate a list of variables that could potentially affect donor behaviour vis-à-vis mental disability charities.

2. To determine the most important variables in the abovementioned list in terms of their contributions to variations in donors' willingness to give to mental disability charities.

3. To create and test a model of charity donation behaviour applicable to mental disability charities.

4. To lay a foundation for future research concerning donors' willingness to support "unpopular" causes.

\section{Importance of the topic}

All countries have substantial numbers of citizens with mental disabilities. The UK, for example, has an estimated 1.9 million residents with an intellectual impairment requiring medical treatment. (This figure includes about 1.1 million individuals with a learning disability, frequently conjoined with other mental problems [for details see DWP, 2018].) Mental illness is a major burden on the UK's national health services, with $28 \%$ of all UK citizens with a reportable disease having a mental health problem. This compares with cancer, which accounts for $16 \%$, and heart disease which is responsible for $16 \%$ (NHS, 2018). Numerous UK charities exist to help individuals affected by mental disabilities. In 2018, the Register of Charities for England and Wales contained 810 charities with a name that included the term "mental disability" or its equivalent. A further 48 charities had a name that incorporated the words "learning disabilities", 26 had the word "eating disorders" in their 
names, 22 had "depression", and 14 had "schizophrenia". Additionally, there were perhaps a further 200 charities that deal with other specialist mental disabilities (suicide, bipolar disorder, etc.) (Charities Commission, 2018). Most of these charities are small (only one appears in the list of the UK's top 1000 charities ranked by donations [Charities Commission, 2018]), but all need to engage in fundraising. In 2013 a government report estimated that the cost of mental disability problems was $£ 70$ to $£ 100$ billion a year and accounted for around $4.5 \%$ of GDP (Davies, 2013).

\section{Literature review}

\section{General factors}

Models of donor behaviour typically compartmentalise variables under headings for the sources of perceptions of a cause, motivations to give (including personality traits), fundraising message strategies, and controls. An influential model of giving was that of Sargeant (1999), subsequently expanded in Sargeant \& Woodliffe [2007] and revisited by Sargeant himself in this journal (Sargeant, 2014). Sargeant grouped variables into categories for motivations (altruism, empathy, sympathy, self-image and self-esteem, warm glow, pity and guilt); socio-economic characteristics; social norms; a charity's image and reputation; a person's financial ability to give and past donation history; and matters to do with message delivery (framing, content, technical quality). Bekkers and Wiepking's (2011) review of models of giving behaviour added "personal values" to the list of variables requiring attention. Further important considerations identified by the charity donation literature are donor perceptions of the efficacy of a charity's operations, donors' exposure to media statements about charities, and the activities of competing charities (Bendapudi et al., 1996; Mainardes et al., 2017; Bennett, 2018). 


\section{Special factors}

Corrigan (2000) examined a number of special factors applicable to fundraising for charities that help people with mental disabilities. These considerations were mainly associated with the stigma that often surrounds public perceptions of mental illness.

\section{Attribution and stigmatic stereotyping}

Goffman (1963) defined stigma as "a mark or attribute that reduces an individual from being a whole and useful person to being a tainted, discounted one" (p.3). Attribution theory provides a framework for understanding stigma in the mental disability context (Gureje, Olley, Olusola \& Kola, 2006), as it traces a path from "signals" and "labels" through to attributed negative stereotypes and hence to discrimination (Stuart, 2008). Attribution is a process whereby individuals assign causes to explain actions or behaviour (Heider, 1958). According to Corrigan (2000), a problem for mental disability charities is that their beneficiaries sometimes transmit attributional signals which encourage discrimination against people with mental disabilities, e.g., odd behaviour and/or unattractive physical appearance, unusual speech, difficulties in learning or understanding. Signals of this type could help create stereotypes of mentally disabled people as inferior human beings who need to be controlled and to be kept away from the public (Corrigan, 2000; Stuart, 2008).

Few non-mentally disabled people have direct personal experience of mental illness and thus learn negative attitudes towards mental disability in childhood and, in later life, through media that often present sensationalised stories about dangerous and violent behaviour among people with mental disabilities (Corrigan, 2000; Kirkwood \& Stamm, 2006). McGinty et al. (2015) noted the high frequency with which TV shows, newspapers, etc., portray mentally disabled individuals in a negative light, e.g., by describing them as "scary psychos" (Oakes, 
2017 p.1). Consequently, public stereotypes of mentally disabled individuals may include assumptions that they are dangerous, childlike, incompetent and unable to do things for themselves (see Pescosolido et al., 1999; Hiday, 2006). Such assumptions beget fear of people with mental disabilities, prejudice, and discrimination (McGinty et al., 2015).

\section{Attribution of controllability}

Wong, Poole and Agius (2015) observed how the attribution of mental ill health to a person often involves perceptions of controllability. A condition may be seen as controllable if an affected individual is assumed capable of influencing or preventing the condition (Weiner, Perry \& Magnusson, 1988). For example, members of the public might regard mental disability resulting from drug or alcohol abuse to be controllable, and hence less worthy of assistance (Fosterling, 2001). Attribution of mental disability to a controllable cause enables some members of the public to reassure themselves that this will never happen to them (Gureje et al., 2006), and arguably encourages people to distance themselves from anything related to mental disability (Wheat, Brohan, Henderson \& Thornicroft, 2010).

\section{Implications for marketing}

Mental disability charities need to ensure that their marketing strategies and activities present their causes as attractive, visible and compelling (Body, 2015). However, fundraising for mental disability charities can be difficult and, as Rochlen and Hayer (2005) observed, might require substantially more time, skill and effort than fundraising for any other type of cause. Corrigan and Shapiro (2010) noted how large parts of a mental disability charity's fundraising advertising that is directed at the general public will be wasted if stigma against 
mentally disabled people causes many individuals to ignore any advertisement which involves mental disability.

\section{Message strategies}

Corrigan et al. (2001) proposed three strategies for changing public attitudes about mental illness, and by implication for improving the fundraising performance of mental disability charities: education, protest and contact.

\section{(a) Education}

Fundraisers can seek to replace myths about mental disability with accurate information and conceptions, thus improving mental health literacy, helping the public to understand mental problems, and reducing stigma (Corrigan, Watson, Warpinski \& Gracia, 2004). Information provision can influence donations directly, and indirectly via social norms (Croson, Handy \& Shang, 2009). Information about a charity's beneficiaries has been found to be valued more highly by potential donors than information about a charity's organisation structure, and financial performance (Leventhal and Foot, 2015), especially information transmitted through social media (Bennett, 2017).

Advertisements in conventional and in social media may be used to educate the public about mental illness. Television companies can be asked to include sympathetic portrayals of people with mental disabilities in programmes; cause-related marketing campaigns may be requested to provide information about mental disability on purchased items. Oakes (2017) concluded that the advertising campaigns of a number of mental disability charities undertaken in 2017 had resulted in the public "becoming more aware of mental disability problems and the need to be more supportive towards those affected". A survey of 10,526 people completed by Sampogna et al. (2017) found that informative social marketing 
campaigns were an important means for reducing stigma associated with mental disability. Likewise, studies by Penn and Couture (2002) and Kirkwood and Stamm (2006) concluded that public information campaigns reduced stigmatisation, especially vis-à-vis perceptions that mentally ill people are potentially violent and dangerous. On the other hand, public mental disability campaigns could cause disquiet among certain members of the public by helping "make it OK to say you're not OK", i.e., wrongly leading people who are experiencing life's normal ups and downs into thinking they are mentally ill.

(b) Protest

Protest messages attempt to suppress negative thoughts regarding mental disability via the "controlled inhibition of unwanted stereotypical thoughts" (Corrigan et al., 2001, p.190). They highlight the injustice of stigmatising people with mental disabilities, and "chastise" people who stereotype and discriminate against mentally disabled people (Corrigan \& Shapiro, 2010 p.912). However, protest strategies can backfire because people who are ordered to suppress negative stereotypes might become more sensitive to images of people with mental disabilities and then begin to harbour negative thoughts about mental disability. In addition, suppression could alter attitudes but not affect behaviour (Penn \& Couture, 2002). Studies by Corrigan (2000) found that protest strategies could diminish negative public attitudes towards people with mental disabilities, but rarely resulted in people having attitudes that are more positive. Protest-related messages within campaigns could be included in "shock tactics" advertising and/or in marketing messages designed to arouse feelings of "guilt" in potential donors. Provocative public relations activities could challenge negative stereotypes of people with mental disabilities.

(c) Contact 
Contacts between the non-mentally disabled and individuals with mental disabilities can improve the former's attitudes regarding the latter (Corrigan et al., 2001; Corrigan, 2000; Corrigan \& Shapiro, 2010). According to Penn and Couture (2002), contact can result in the psychological reclassification of people with mental disabilities in the minds of non-mentally disabled people, particularly in relation to whether mental disorders are attributable to people with mental disabilities themselves. Whereas educational and protest messages can readily be incorporated into advertisements, contact with people with mental disabilities must be mimicked within advertisements indirectly. Thus, advertisements need to offer representations of reality that imitate contacts between non-mentally disabled people and people with mental disabilities (see Bennett, 2018). The content and form of an advertisement must be arranged in ways that stimulate thoughts, feelings and actions relevant to contacts. Contact images could be particularly useful for demonstrating that many people with mental disabilities can hold down jobs and live relatively "normal" and independent lives (cf. Corrigan, 2000).

\section{Research method}

The research proceeded in two stages; the first involving the production of a list of variables potentially influencing a person's willingness to donate to a mental disability charity. This list was shortened via a random forest regression. Stage two comprised the creation and testing of a structural equation model based on the variables identified by the random forest regression. A synthesis of the variables listed in (i) the pre-existing comprehensive models of donor behaviour, and (ii) considerations specific to mental disability, generated 24 variables that past studies indicate might influence a person's willingness to donate to a mental disability charity, as shown in Table 1. 
Although measures of empathy, altruism and the other trait variables listed in Table 1 typically comprise multiple items, it was not possible in the present study to include the full inventories for these constructs because this would have resulted in a questionnaire that was so long that few members of the public would be prepared to complete it. Also, "yea-saying" would be likely among people who did participate. Therefore, stage one of the study employed single items or two or three items to measure these constructs. Reduced-form measures require less cognitive effort from respondents, are easy to administer, are reasonably reliable when measuring straightforward constructs, and have been successfully applied to many areas of business research (Drolet \& Morrison, 2001; Diamantopoulos et al., 2012). Single item or reduced-form measures are suitable for situations, such as in the present research, where constructs are mostly concrete, where one or two items can capture the essence of a construct, and where a questionnaire would otherwise be too daunting for participants (Drolet \& Morrison, 2001; Bergkvist, 2015).

A questionnaire containing items for the 24 variables was created and discussed with (i) two senior managers in a large national mental disability charity, and (ii) the director and deputy director of a small mental disability charity that operates in the south east of England. These discussions led to the rewording of certain items, although all four of the charity managers agreed that the items broadly captured potential donors' likely motivations to give to a charity in the mental disability field. Table 1 lists the items (and where appropriate the sources from which items were derived), plus three items assessing willingness to donate. The items selected as representative measures of the trait constructs were those that past literature has found to offer the highest levels of explanation of the construct in question. Item five concerning income queried a person's income circumspectly, given that many people dislike being asked directly about their financial status. Item 18 on the activities of competing charities was specially constructed for the present study. The questionnaire began with a 
definition of mental disability as a disability that interferes with a person's ability to live independently and to complete normal daily activities. Examples taken from MIND (2013) were given following the statement of the definition; namely schizophrenia, phobias, hearing voices, severe learning disability, paranoia, obsessive disorders, severe depression.

\section{TABLE 1. QUESTIONNAIRE ITEMS}

Unless otherwise stated, five-point agree/disagree scale were used to measure constructs.

\begin{tabular}{|c|c|c|c|}
\hline $\begin{array}{c}\text { FACTUAL QUERY } \\
\text { OR CONSTRUCT } \\
\text { MEASURE }\end{array}$ & QUESTIONNAIRE ITEM & SOURCE & $\begin{array}{c}\text { RFR RANK } \\
\text { (\% of variation } \\
\text { explained in } \\
\text { parentheses) }\end{array}$ \\
\hline 1. Age & $\begin{array}{l}\text { Category in years: } 18-25 ; 26- \\
33 ; \text { etc. }\end{array}$ & & \\
\hline 2. Gender & Male or female & & \\
\hline 3. Ethnicity & $\begin{array}{l}\text { Black, White, Indian Sub- } \\
\text { Continent, Chinese, Other }\end{array}$ & & \\
\hline 4. Education & $\begin{array}{l}\text { Highest qualification on leaving } \\
\text { education (options listed, e.g., } \\
\text { undergraduate degree, BTEC, } \\
\text { A' Levels; GCSE }\end{array}$ & & \\
\hline 5. Income & $\begin{array}{l}\text { Relative to other people I know, } \\
\text { I would say that I am } \\
\text { financially better off/about the } \\
\text { same/worse off }\end{array}$ & & \\
\hline 6. Religion & $\begin{array}{l}\text { Overall, I would say that I am a } \\
\text { religious person }\end{array}$ & & $\begin{array}{l}5 \\
(9 \%)\end{array}$ \\
\hline $\begin{array}{l}\text { 7. Giving to } \\
\text { charities in general }\end{array}$ & I regularly give to charities & & \\
\hline 8. Altruism & $\begin{array}{l}\text { (a) I feel a strong personal } \\
\text { moral obligation towards the } \\
\text { welfare of others } \\
\text { (b) I take pleasure in helping } \\
\text { others } \\
\text { (c) My friends would say that I } \\
\text { am an altruistic person }\end{array}$ & $\begin{array}{l}\text { Schwartz, S. } \\
\text { (1977) }\end{array}$ & $\begin{array}{l}2 \\
(11 \%)\end{array}$ \\
\hline 9. Affect intensity & $\begin{array}{l}\text { (a) My happy moods are so } \\
\text { strong that I feel that I'm in } \\
\text { heaven } \\
\text { (b) When I do feel anxiety, it is } \\
\text { normally very strong }\end{array}$ & Larsen (1984) & $\begin{array}{l}9 \\
(6 \%)\end{array}$ \\
\hline
\end{tabular}




\begin{tabular}{|c|c|c|c|}
\hline & (c) Sad stories deeply touch me & & \\
\hline $\begin{array}{l}\text { 10. Tendency to } \\
\text { experience } \\
\text { helper's high }\end{array}$ & $\begin{array}{l}\text { (a) Donating to charity gives } \\
\text { me a huge amount of pleasure } \\
\text { (b) Donating to charity gives } \\
\text { me a warm feeling and deep } \\
\text { personal satisfaction } \\
\text { (c) Giving to charity makes me } \\
\text { feel good about myself }\end{array}$ & $\begin{array}{l}\text { Bennett \& Gabriel } \\
\text { (1999) }\end{array}$ & \\
\hline $\begin{array}{l}\text { 11. Congruence of } \\
\text { self-image with the } \\
\text { act of giving to a } \\
\text { mental disability } \\
\text { charity }\end{array}$ & $\begin{array}{l}\text { (a) The image of people who } \\
\text { give money to mental disability } \\
\text { charities is highly consistent } \\
\text { with how I see myself } \\
\text { (b) I am very much like the } \\
\text { typical person who donates to } \\
\text { mental disability charities } \\
\text { (c) I cannot relate to people } \\
\text { who would rather donate to a } \\
\text { mental disability charity than to } \\
\text { other types of charity }\end{array}$ & $\begin{array}{l}\text { Sirgy, Johar \& } \\
\text { Claiborne (1992) }\end{array}$ & $\begin{array}{l}1 \\
(15 \%)\end{array}$ \\
\hline 12. Empathy & $\begin{array}{l}\text { (a) I am often deeply touched } \\
\text { by what I see happening to } \\
\text { others } \\
\text { (b) I find it easy to see things } \\
\text { from the other person's point of } \\
\text { view } \\
\text { (c) I feel very protective of } \\
\text { people who I see being taken } \\
\text { advantage of }\end{array}$ & Davis (1983) & \\
\hline 13. Sympathy & $\begin{array}{l}\text { I feel sympathy for people with } \\
\text { mental disabilities }\end{array}$ & Bennett (1997) & $\begin{array}{l}4 \\
(9 \%)\end{array}$ \\
\hline 14. Pity & $\begin{array}{l}\text { I pity people with mental } \\
\text { disabilities }\end{array}$ & Bennett (1997) & \\
\hline 15. Values & $\begin{array}{l}\text { The values of mental disability } \\
\text { charities are clear and easy to } \\
\text { understand }\end{array}$ & Stride (2006) & \\
\hline $\begin{array}{l}\text { 16. Prior } \\
\text { knowledge of } \\
\text { mental illness }\end{array}$ & $\begin{array}{l}\text { I know a lot about mental } \\
\text { illness }\end{array}$ & $\begin{array}{l}\text { Park \& Lessig } \\
\text { (1981) }\end{array}$ & \\
\hline 17. Social norms & $\begin{array}{l}\text { Many of the people I know } \\
\text { (friends, relatives, workmates, } \\
\text { etc.) have negative views and }\end{array}$ & Wilson (1960) & $\begin{array}{l}6 \\
(8 \%)\end{array}$ \\
\hline
\end{tabular}




\begin{tabular}{|c|c|c|c|}
\hline & $\begin{array}{l}\text { attitudes regarding people with } \\
\text { mental disabilities }\end{array}$ & & \\
\hline $\begin{array}{l}\text { 18. Activities of } \\
\text { competing } \\
\text { charities in other } \\
\text { sectors }\end{array}$ & $\begin{array}{l}\text { I see and receive very many } \\
\text { requests from charities asking } \\
\text { me to give them money }\end{array}$ & $\begin{array}{l}\text { Specially } \\
\text { constructed for the } \\
\text { present study }\end{array}$ & \\
\hline $\begin{array}{l}\text { 19. Opinion of the } \\
\text { efficacy of mental } \\
\text { disability charities }\end{array}$ & $\begin{array}{l}\text { I believe that mental disability } \\
\text { charities use their incomes } \\
\text { wisely and provide high-quality } \\
\text { services to the mentally } \\
\text { disabled people they help }\end{array}$ & $\begin{array}{l}\text { Sargeant \& } \\
\text { Woodliffe (2007) }\end{array}$ & \\
\hline $\begin{array}{l}\text { 20. Stigmatic } \\
\text { stereotyping of } \\
\text { people with mental } \\
\text { disabilities }\end{array}$ & $\begin{array}{l}\text { People with mental disabilities } \\
\text { are: } \\
\text { (a) Dangerous } \\
\text { (b) Scary } \\
\text { (c) Potentially violent } \\
\text { (d) Intimidating } \\
\text { (e) Threatening } \\
\text { (f) Generally unpleasant }\end{array}$ & $\begin{array}{l}\text { Corrigan }(2000) \\
\text { Corrigan } \& \\
\text { Shapiro }(2010)\end{array}$ & $\begin{array}{l}3 \\
(10 \%)\end{array}$ \\
\hline $\begin{array}{l}\text { 21. Signals: } \\
\text { - Educational } \\
\text { - Protest }\end{array}$ & $\begin{array}{l}\text { (a) I have seen many public } \\
\text { information campaigns that } \\
\text { factually explain issues } \\
\text { concerning mental disability } \\
\text { (b) I have seen many public } \\
\text { information campaigns that } \\
\text { focus on the unfairness and } \\
\text { injustice concerning the ways in } \\
\text { which people with mental } \\
\text { disabilities are treated }\end{array}$ & $\begin{array}{l}\text { Created for the } \\
\text { present study on } \\
\text { the basis of } \\
\text { Corrigan }(2000) \\
\text { and Corrigan \& } \\
\text { Shapiro }(2010)\end{array}$ & $\begin{array}{l}7 \\
(7 \%)\end{array}$ \\
\hline - Contacts & $\begin{array}{l}\text { (c) I have seen many TV } \\
\text { programmes, films, newspaper } \\
\text { or magazine articles that show } \\
\text { people with mental disabilities } \\
\text { freely and happily interacting } \\
\text { with non-mentally disabled } \\
\text { people }\end{array}$ & & $\begin{array}{l}8 \\
(7 \%)\end{array}$ \\
\hline 22. Image & $\begin{array}{l}\text { Mental disability charities have } \\
\text { a good public image }\end{array}$ & $\begin{array}{l}\text { Bennett \& Gabriel } \\
(2003)\end{array}$ & \\
\hline 23. Reputation & $\begin{array}{l}\text { Mental disability charities have } \\
\text { excellent reputations }\end{array}$ & $\begin{array}{l}\text { Bennett \& Gabriel } \\
\text { (2003) }\end{array}$ & \\
\hline 24. Attribution & $\begin{array}{l}\text { Many people with mental } \\
\text { disabilities only have } \\
\text { themselves to blame for their } \\
\text { condition }\end{array}$ & $\begin{array}{l}\text { Corrigan \& } \\
\text { Shapiro (2010) }\end{array}$ & \\
\hline $\begin{array}{l}\text { 25. Willingness to } \\
\text { give to a mental } \\
\text { disability charity }\end{array}$ & $\begin{array}{l}\text { (a) I am very willing to donate } \\
\text { to a mental disability charity }\end{array}$ & & \\
\hline
\end{tabular}




\begin{tabular}{|c|c|}
\hline & $\begin{array}{l}\text { (b) I intend giving money to a } \\
\text { mental disability charity } \\
\text { (c) There is no doubt that in the } \\
\text { future I will donate to a mental } \\
\text { disability charity }\end{array}$ \\
\hline
\end{tabular}

\section{The first sample and initial analysis}

Three hundred and three 303 adult members of the public belonging to a commercial consumer panel completed the questionnaire. The panel company's filter excluded individuals with a direct link to someone with a mental illness or disability. A further 101 completed questionnaires were gathered by the authors. (The results from the two groups were broadly similar, so the two sets of responses were combined into a single sample.) As the nature of the research gave rise to the possibility of social desirability bias in responses (i.e., the risk that some participants would understate their hostility to people with mental disabilities in order to appear altruistic and "politically correct"), the first section of the questionnaire contained the eight-item short-form version of the Marlowe-Crowne social desirability scale (Reynolds, 1982). Examples of these items are "Have there been occasions when you took advantage of someone?" and “Are you quick to admit making a mistake?" (For details of the items and of the scoring system for the scale see Ray [1984].) The researchers correlated the responses to these items with replies to the remainder of the questionnaire and suspicious cases were further analysed, e.g., by examining whether responses were particularly high for questionnaire items where social desirability bias was especially likely. This led to the removal of 16 responses. As expected from items taken from previously validated inventories, each set of three items used to measure the trait constructs (altruism, etc.) was significantly and substantially intercorrelated ( $\mathrm{R}>.81$ in all cases). Hence, 
the items for each of the trait constructs were averaged to form single item measures, as were the three items assessing willingness to donate (variable $25, \mathrm{R}=.82$ ).

\section{Initial analysis}

The construction of a parsimonious predictive model required the reduction of the number of variables to be included in a further analysis. This was achieved via a random forest regression (Ho, 1995; Breiman, 2001) undertaken to determine the relative importance of each of the (single item) variables for predicting a person's willingness to donate to a mental disability charity. Random forest regression (RFR) is useful in discovery-orientated situations where a very large number of regressors potentially influence a dependent variable. It is a machine learning method which predicts values of a dependent variable by partitioning data into subsets that contain instances with similar values. The method constructs learning trees for the values of the independent variables and the results are merged to obtain predictions. RFR captures non-linear relationships between the independent variables and the target variable, can include any number of independent variables, is mostly unaffected by multicollinearity, and is non-parametric so that no assumptions need be made regarding the distributions of the variables [normality for instance]). Variables may be categorical, binary or continuous. The regression output ranks the independent variables in order of their importance in explaining variation in the dependent variable.

RFR is however, a "black box" technique that does not create regression coefficients with Tvalues and significance levels. Rather, it offers "straight" regression results where a single dependent variable is regressed on all of the independent variables simultaneously, ignoring possible interrelationships among the independent variables. This situation was acceptable in the present study because the research sought to identify differences between the variables 
known to affect donor behaviour in general models of giving and the variables that are most important in influencing willingness to give to mental disability charities.

Although alternative techniques are available for reducing the dimensions of an analysis, they were not suitable for use in the present study. Cluster analysis or factor analysis will group together items with similarities, but do not relate them to a dependent variable. Also, many of the items listed in Table 1 are likely to appear in many different factors and to have approximately equal factor loadings. Pairwise correlations will show that several variables correlate significantly with a dependent variable, but do not take into account the influences of other variables. In addition, pairwise correlations do not indicate which of several significantly inter-correlated variables should appear in a final model. It was not appropriate to assess stigmatic stereotype using an Implicit Association Test (IAT) as this would require special set-ups on participants' computer hardware, and lengthy instructions would have to be provided (Greenwald, McGhee \& Schwartz, 1998). The options offered within an IAT would be no different to those stated in Table 1.

\section{Results}

Nine variables were especially important for explaining variation in willingness to donate to a mental disability charity. Table 1 shows the rank of each of the nine variables and the percentage of variation it explained. Self-congruence was the most important variable, explaining $15 \%$. The nine variables from self-congruence through to affect intensity collectively explained $82 \%$ of total variation. None of the remaining variables explained more than $1.4 \%$ of total variation.

\section{Low ranking variables}


Empathy explained little variation in the participants' willingness to give to this particular type of charity, suggesting that a highly empathetic person might deeply empathise with people with mental disabilities, yet still dislike them. Seeing and understanding what a mentally ill person is going through might remind empathetic individuals that they too might one day experience mental illness, and these thoughts might be disagreeable and hence lead to negative reactions to the fundraising appeals of mental disability charities (cf. Bennett, 1997). Bekkers (2005) observed that empathy might be a moderator of the intentionbehaviour relationship rather than a direct influence on donation intention. However this matter that could not be explored using the present methodology. Also, empathy has been found to interact with altruism (see Wiepking, 2010) and with feelings of guilt (Basil, Ridgway \& Basil, 2008). Again, an examination of these possibilities was beyond the remit of the current study.

An explanation of the low ranking of educational messages might be the fact that the study was undertaken in the UK at a time when large amounts of information about mental illness were appearing in the media due to Royal and celebrity endorsements and to government initiatives in the area. Hence, educational messages may have been commonplace at the time and unable to affect stigmatic stereotyping. A further possibility is that a substantial number of the sample members would not want to be disturbed by educational messages about people with mental disabilities due to the negative thoughts that such messages might trigger (Corrigan et al., 2004. Likewise, attribution of blame for mental disability to people with mental disabilities themselves was an unimportant variable, due also perhaps to the substantial volume of information distributed about mental illness at the time the study was completed. As noted by Corrigan (2000), moreover, attributions by members of the public can vary greatly with respect to various types of mental disability. 
Prior knowledge of mental illness explained little variation in the dependent variable, suggesting that some people with much knowledge of mental illness also dislike people with mental disabilities. A number of the participants may have "picked" up negative attitudes during childhood exposure to people with mental disabilities (Hazzard, 1983); others might have associated fear with mental disability (Corrigan et al, 2004). "Warm glow" was unimportant, arguably because potential donors expect less warm glow when people consider giving to mental disability charities as opposed to more "popular" charities (children, cancer, animals, etc.) (Williamson \& Clark, 1989). In a study of subjective influences on charity giving, Berman, Barasch, Levine and Small (2018) concluded that warm glow might be greatest when giving to people with whom donors have a connection. The perceived efficacy of a mental disability charity was also unimportant, possibly since many members of the public regard mental disability charities as efficient but are still reluctant to give to them. Charity efficiency is a complex and multifaceted issue about which donors are unlikely to know the precise details, leading perhaps to an absence of strong opinions (Charity Watch, 2019).

The unimportance of whether a person gave a lot of money to charities in general might indicate that, simply because an individual is generous when giving to the charity sector as a whole, this does not mean that the person is prepared to support charities that deal with mental disability. Bennett (2018) reported a large volume of literature attempting to identify the "giving type" vis-à-vis charity donation, but few of the studies involved dealt with mental disability. Ignorance and negative cultural stereotyping relating to mental disability might affect generous givers just as much as people who donate lesser amounts to charity (Henderson \& Thornicroft, 2009).

Females tend to give more to charity than males and, according to CAF (2018), the gap is widening. In the present study, however, males were more inclined to give to mental 
disability charities than females. An examination of the data revealed a substantial pointbiserial correlation between female gender and stereotypical beliefs that mentally ill people are dangerous $(\mathrm{R}=.44)$ and potentially violent $(\mathrm{R}=.42)$, and this might explain a reluctance of some females to support mental illness charities. Piper and Schnepf's (2008) study of gender differences in charity giving found that, compared with other genres of cause (animal welfare, hospices, etc.), gender disparities relating to mental disability were very small. Age was unimportant in this study, reflecting perhaps the likelihood that older and younger UK people experience similar levels of exposure to mental illness (Westerhof \& Keyes, 2010), with similar implications for giving to mental disability charities (NPT, 2018). Financial status did not figure in the list of the most important variables, indicating that attitudes towards donating to mental disability causes did not vary substantially with respect to social status (cf. Corrigan, 2000; Corrigan et al., 2004a).

\section{Construction of a model}

A tentative model was constructed based on the nine main variables identified by the RFR, as presented in Figure 1. In the main, the model shows the processes involved in the assumed donation behaviour. Direct effects and possible contingencies that might affect the strengths of relationships between variables were measured; alternative configurations were examined; interactions were probed and indirect effects were considered. In line with much academic literature, which typically regards altruism, self-congruence and affect intensity as innate tendencies with powerful direct impacts on giving behaviour (see Bekkers \& Wiepking, 2011; Bennett, 2018); these variables were assumed to have direct effects on willingness to donate. Altruism, according to Andreoni (1990), furnishes the donor with positive utility from the very act of giving. It has been found to have links with warm glow and the pursuit of 
egoistic benefits from donating to charity (Rushton, 1984). An extensive literature supports the presence of self-congruence in a model of donor behaviour (see Shang, Reed \& Croson, (2008). This also applies to religiosity (see Ranganathan \& Henley, 2008; Bekkers \& Wiepking, 2011), which is posited to exert a direct and independent effect on willingness to donate. Religiosity allegedly motivates an individual to give "out of a sense of duty" (Ranganathan \& Henley, 2008). Interestingly in relation to the present study, Neumayr and Handy (2017) found religiosity to be associated with support for particular types of charity. Stigmatic stereotyping (a characteristic possibly learned in childhood and in later life through exposure to messages in advertisements, television programmes, movies, newspapers and magazines [Stuart, 2006]) is deemed to be affected by exposure to protest messages that challenge unfair discrimination towards the mentally disabled and to contact messages that show how people with mental impairments can lead normal lives. Protest "seeks to suppress negative attitudes and representations of mental illness" (Corrigan et al., 2001 p.187), although it could rebound through creating unwanted recollections of the stigmatised group (Macrae, Bodenhausen, Milne and Wheeler, 1996). A possible problem with contact messages is that prejudiced people might ignore them while individuals who do not stigmatise may watch and enjoy them assiduously (Wahl, 1995).

The influences of contact and protest messages on reducing levels of stigma associated with mental disability among potential donors could be stronger among people with high affect intensity. The term 'affect intensity' describes the strength of the emotions that individuals feel when responding to everyday events and, in particular, to emotion-inducing incidents (Bennett, 1997). Thus, a person with high affect intensity (HAI) might be expected to react to emotive events and communications in a deeply emotional manner, and vice versa (Larsen, 2009). Moreover, the emotions aroused could play an important role in attitude formation and change (Moore, 1995). Contact and protest messages might also arouse feelings of sympathy 
("understanding another's plight) for people with mental disabilities and, independently, might influence willingness to donate. Corrigan et al. (2012) and Ewalds-Kvist, Hogberg and Lutzen (2012) reported several studies which found that less sympathy towards people with mental disabilities is shown by people with limited past exposure to messages about mental illnesses. Figure 1 is in line with past research which suggests that many people subjectively construct sympathy for a charitable cause not only on the basis of their own personal experiences of isues relating to the cause, but also through contacts with the cause (Body and Breeze, 2016). Affect intensity could positively moderate the suggested connection between sympathy and willingness to donate.

Social norms (i.e., the influences of friends, relatives, social networks, etc. and the example set by important others in relation to mental illness) are likely to have a negative impact on stigmatic stereotyping and a direct positive effect on the dependent variable. The role of social norms in charity giving has been studied extensively. Typically, studies have reported positive connections, including results from studies involving specific sub-groups of donors (see Croson et al., 2009). Sanghera (2016) suggested that social norms are associated with "lay morality", i.e., that social norms articulate, formalise and legitimise a person's views on ethical issues of justice and what is right and wrong. Norms are learnt and developed, Sanghera (2016) continued, through ongoing social interaction. 
FIGURE 1. A TENTATIVE MODEL

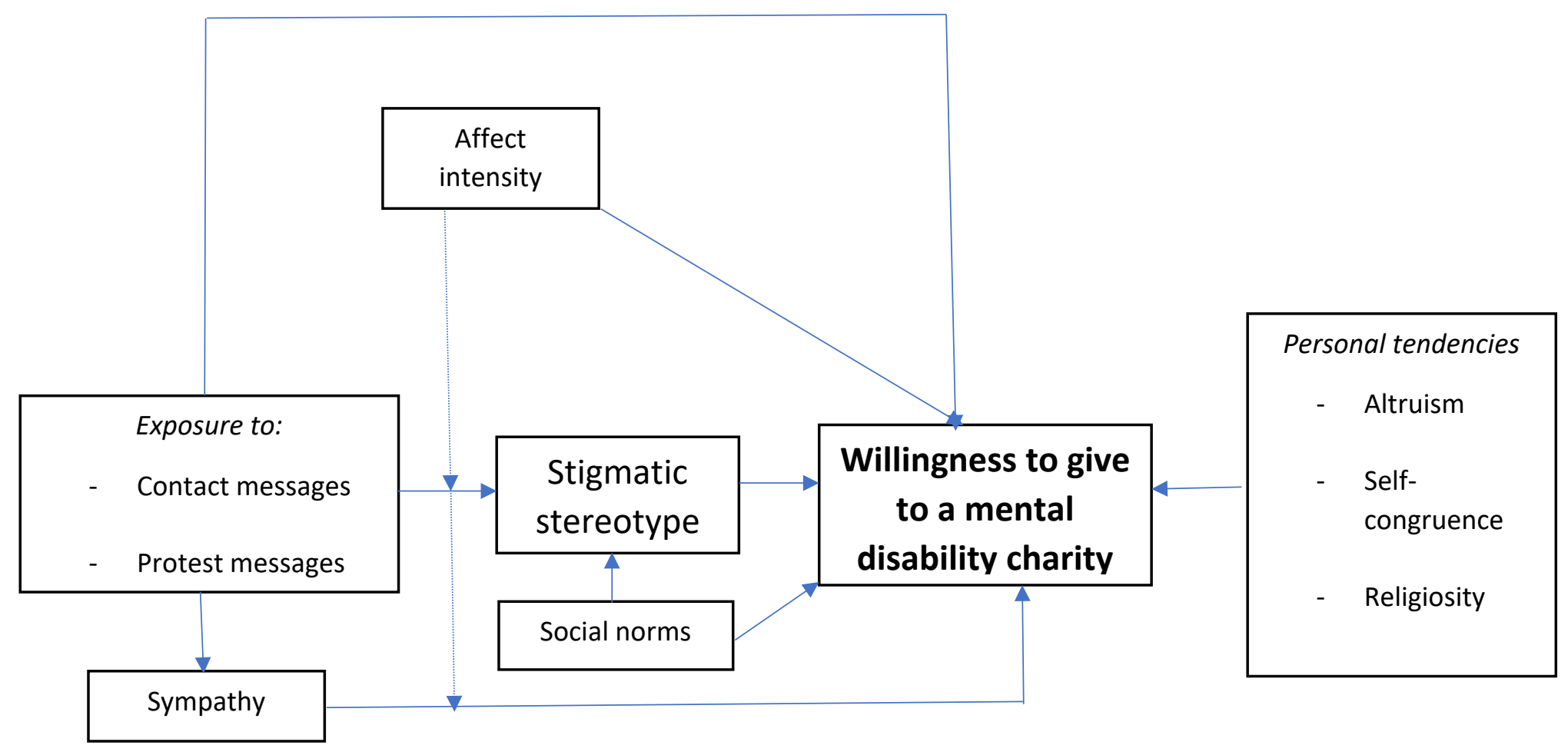


Figure 1 presents a fresh and parsimonious configuration of variables familiar from preexisting models of donor behaviour plus variables not previously included in such models. The model is testable and, critically, is specifically relevant to mental disability.

\section{Test of the model}

A fresh questionnaire containing the full versions of short-form inventories for altruism (20 [brief] items [Rushton, Chrisjohn \& Fekken, 1981), self-congruence (eight items [Sirgy \& Su, 2000]), affect intensity (20 [very brief] items [Larson, 2009]), social desirability (four items adapted from Ajzen \& Fishbein [1980]), stigmatic stereotype (six items) plus items for the other Figure 1 variables was completed by 305 members of a commercial consumer panel and by 128 members of the public approached by the authors and by students who were trained and paid for the task. There was no substantial difference in the pattern of the results obtained from each group, which were merged into a single sample. Factor analyses of the sets of items for altruism, self-congruence, affect intensity and social norms generated unidimensional solutions (as expected from these extensively validated instruments), with all four leading eigenvalues explaining more than $80 \%$ of total variation. As the variables were normally distributed to acceptable levels, Figure 1 was estimated using the AMOS package of IBM Statistics. Table 2 presents the all-sample results. All pathways were significant at the .05 level or below and the diagnostics obtained from the estimation indicated a good fit: $\mathrm{CFI}=.98 ; \mathrm{GFI}=.93, \mathrm{AGFI}=.90 ; \chi^{2} / \mathrm{df}=1.99 ; \mathrm{RMSEA}=.06$. There was no evidence of substantial multicollinearity among the explanatory variables $(\mathrm{R}<.51$ in all cases $)$. Alternative configurations of mediating and moderating influences were examined on an experimental basis, none proving superior to the outcome shown in Table 2 . 
TABLE 2. TEST OF THE MODEL

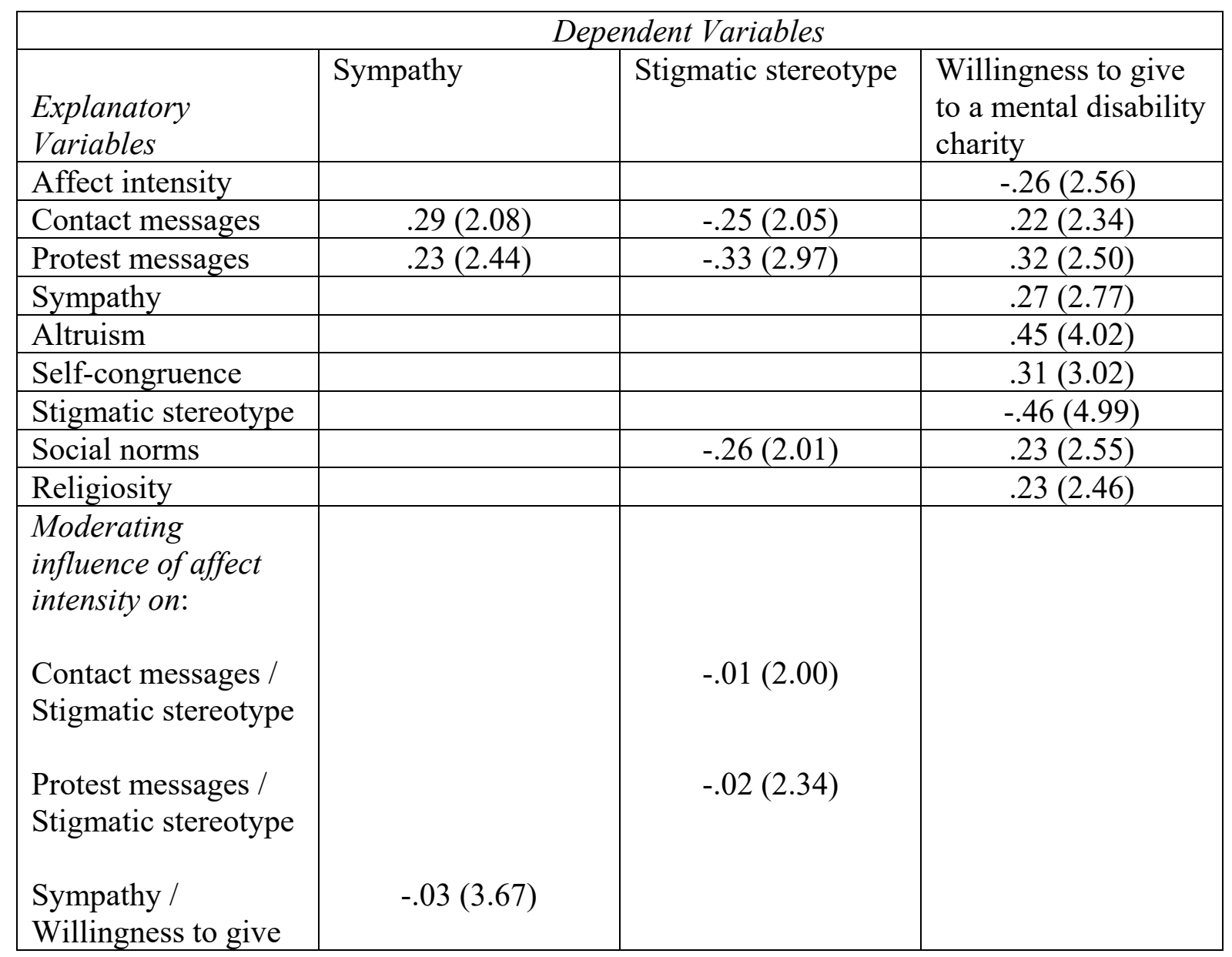

T-values in parentheses. All coefficients significant at the .05 level or below. 
It can be seen from Table 2 that stigmatic stereotype and altruism exerted the biggest influences on willingness to donate, followed by self-congruence. On average, exposure to contact messages and protest messages significantly reduced the participants' levels of stigmatic stereotyping of mentally disabled people and had significantly positive impacts on willingness to donate. Affect intensity had a significantly negative influence on willingness to give, and modified the effect of contact and protest messages in the downwards direction. The (positive) effect of sympathy on willingness to give was also modified downwards by affect intensity. People who regarded themselves as religious were more likely than others to donate to a mental disability charity. Social norms significantly reduced stigmatic stereotyping and increased willingness to donate.

Affect intensity exerted a negative effect both as a determinant of willingness to donate and as a moderator of the relations between contact messages, protest messages, and stigmatic stereotyping. In the case of the moderated linkages, contact and protest messages had less of an impact on reducing stigmatic stereotyping among people with high affect intensity. Individuals with high affect intensity might feel uncomfortable with the idea of mental impairment and the discomfort may be felt more deeply the higher the level of affect intensity (cf. Moore, 1995; Hibbert, Smith, Davies and Ireland, 2007). When confronted with messages about mental illness via contact or protest images, a high affect intensity person might respond to them negatively. A study by Moore (1995) observed how high affect intensity people felt great discomfort when confronted with messages that evoke painful thoughts, leading to avoidance reactions and behaviour.

\section{Conclusion}


This study sought to develop a model of giving behaviour for use in an area, mental disability, where no previous models specifically related to mental disability were available and where a large number of variables could influence decisions to give. A random forest regression was completed to reduce the number of variables for further examination, and the remaining variables were used to construct a model relevant to mental disability. Outcomes from the investigation confirm that pre-existing general models of donor behaviour need to be amended in order to predict successfully donors' willingness to give to a mental disability charity. Several variables found in pre-existing general models of charity donation behaviour apply to mental disability (altruism, sympathy, religiosity, affect intensity, social norms and self-congruence), as do a number of variables directly associated with mental illness (e.g., stigmatic stereotyping, exposure to messages of a certain kind). These variables should be incorporated into a predictive model.

As regards altruism, the results are compatible with Andreoni's (1990) argument that altruism is independent of other "emotional influences" on giving behaviour (p.464). Affect intensity appears to exert a substantial and significantly negative influence on people's willingness to donate to mental disability, suggesting that disagreeable thoughts are aroused when high affect intensity individuals are confronted with messages that involve mentally disabled people (via, for example, protest or contact themed fundraising advertisements) (cf. Shaffer \& Graziano, 1983; Bennett, 2018). Empathy did not figure in the list of variables obtained from the random forest regression. Possibly, deep feelings of empathy with mentally ill people give rise to unpleasant feelings of sadness and depression (see Bennett, 1997).

\section{Managerial implications}


A number of practical implications arise from the research. The results imply that, without amendment, "one-size-fits-all" models of donor behaviour are unlikely to be relevant for "unpopular" charities. Rather, the sort of model presented in the above sections might usefully be adapted for use in other specialist and unpopular cause areas (e.g., dementia, prisoner rehabilitation, narcotics abuse). Future studies might examine this possibility. According to the outcomes to the present investigation, fundraising campaigns that appeal to donors' altruistic sentiments are likely to be effective, as are campaigns based on selfcongruity messages that "people like me" donate to mental disability charities. MacQuillan, Sargeant and Shang (2016) noted the usefulness of cultivating among donors a sense of psychological identity that involves a supported charity. Psychological identity could, the authors continued, lead to a lasting relationship.

Social norms constituted a significant variable within the model, and mental disability charities should include messages related to social norms within campaigns. Today, "social norms marketing" (SNM) occupies a prominent role in the social marketing canon (see Wesley Schultz et al., 2007). It seeks to adjust a person's attitudes and behaviour to those presumed to exist among a majority of the individual's respected others. SNM has been found to be especially valuable in scenarios where attitudes and behaviour are based on misinformation and misperceptions and where members of the public passively accept misinterpretations (Cialdini et al., 2006). Clearly, SNM has much to offer to fundraisers of charities that deal with unpopular causes.

The study confirms that stigma against people with mental disabilities remains a major problem facing mental disability charities (see Corrigan, 2000; Corrigan \& Shapiro, 2010), and is one that needs to be challenged. This might be achieved via contact and protest messages, especially the latter when embedded within a shock tactics campaign (see Dahl, 2018). Results from the present study show that affect intensity is likely to reduce the impacts 
of contact and protest messages: people who feel their emotions extremely strongly might respond less positively to messages of this kind. Nevertheless, the outcomes underline the potential importance of fundraising campaigns that include protest and contact messages.

\section{Limitations and suggestions for future research}

The study was completed in a single country and covered just one category of charitable cause: mental disability. Separate investigations are needed for charities that deal with alternative unpopular causes. A further limitation of the study is that the dependent variable was intention to donate and not actual donation. Intention to give is not the same as actual charity giving. Bekkers (2005) identified several variables that may affect the donation intention-behaviour relationship. Future research into this matter within the mental disability area would be valuable. Extensions of the model portrayed in Figure 1 to incorporate variables relevant to other types of unpopular cause (immigration assistance, prisoner rehabilitation, etc.) could help fundraisers to create effective campaigns for various kinds of unpopular cause. Within the present investigation, members of the public were questioned about their intentions to give to people with mental disabilities, treating the latter as a generic collection of people. However, mental illness covers a wide range of issues ranging from acute depression through to eating disorders, various phobias and manias, schizophrenia, bipolar disorder, obsessive compulsive disorder, hallucinations and delusions, borderline personality disorder, etc., each with its own image and special marketing communications problems (Brockman, D’Arcy, \& Edwards, 1979). Thus, even within the domain of mental illness generally, research into giving behaviour pertaining to particular kinds of illness might be needed in order to establish the independent variables and model configurations that apply to each specific cause. 
The variables in Figure 1 were selected on the basis of their rankings in a random forest regression. Experiments were conducted using alternative variables and model configurations; but none performed better than the model shown in Figure1. However, whilst the resulting model exhibited good predictive power, there is no guarantee that the correct variables were identified. Additional variables not considered in the present research might affect willingness to give. Future research might determine such variables. The finding that affect intensity exerted negative effects was not expected, and merits further investigation. The negative consequences of affect intensity could be damaging, so it may be necessary to find ways of reaching out to and influencing people who are high in this characteristic. Another promising area for further research concerns the willingness of businesses to donate to mental disability charities. Little is known about this matter, yet corporate support can be of great value to charities in the mental disability field. Research into the factors that encourage or hinder corporate support, the decision-making processes concerning the issue, employee attitudes towards company donations to mental disability charities, etc., would be extremely valuable.

\section{End note}

1. Academic and governmental literature employs a wide range of terms (often with overlapping meanings) when discussing mental health issues. "Mental disorders" involve problems that have been diagnosed and require psychiatric treatment, e.g., bipolar disorder, schizophrenia, phobias, severe depression). "Mental illness" includes mental disorders and problems that might not have been diagnosed (e.g., among people in psychiatric distress but who have not sought assistance). Mental illness becomes a "mental disability" when it interferes with a person's ability to live independently and manage daily activities (OECD, 
2010). The present paper uses the term mental disability to describe the conditions affecting the beneficiaries of the charities covered by the research. 


\section{References}

Ajzen, I. \& Fishbein, M. (1980), Understanding Attitudes and Predicting Social Behaviour, Englewood Cliffs NJ, Prentice-Hall.

Andreoni, J. (1990), Impure altruism and donations to public goods: A theory of warm glow giving, Economic Journal, 100, 464-477.

Basil, D., Ridgway, N. \& Basil, M. (2008), Guilt and giving: A process model of empathy and efficiency, Psychology and Marketing, 25 (1), 1-23.

Batty, D. (2004), Government unveils drive to combat mental disability stigma, The Guardian, 14 June 2004, accessed on 9 October 2018 from www.theguardian.com.

Bekkers, R (2005) “Words and Deeds of Generosity: Are Decisions About Real and Hypothesised Money Really Different?", Working Paper, Department of Sociology, Utrecht, University of Utrecht.

Bekkers, R. \& Wiepking, P. (2011), A literature review of empirical studies of philanthropy: Eight mechanisms that drive charitable giving, Nonprofit and Voluntary Sector Quarterly, 40 (5), 924-973.

Bendapudi, N., Singh, S. \& Bendapudi, V. (1996), Enhancing helping behaviour: An integrative framework for promotion planning, Journal of Marketing, 60 (July), 33-49.

Bennett, R. (1997), They shouldn't let them out for us to see: Empathy and affect intensity as determinants of responses to representations of the facially disfigured in charity advertising, Journal of Nonprofit and Voluntary Sector Marketing, 2 (3), 216-232.

Bennett, R. (2018), Nonprofit Marketing and Fundraising, London, Routledge. 
Bennett, R. \& Gabriel, H. (1999). Charity involvement and customer preference for charity brands. Journal of Brand Management, 7 (1), 49-66.

Bennett, R. \& Gabriel, H. (2003), Image and reputational characteristics of UK charitable organisations: An empirical study, Corporate Reputation Review: An International Journal, 6 (3), 276-299.

Bergkvist, L. (2015), Appropriate use of single-item measures is here to say, Marketing Letters, 26 (3), 245-255.

Berman, J., Barasch, A., Levine, E \& Small, D. (2018), Impediments to effective altruism: The role of subjective preferences in charitable giving, Psychological Science, 29 (5), 834 844.

Body, A. (2015), Foundations have an important role to play in helping "unpopular" causes, Alliance Magazine, 9 July 2015, accessed on 16 October 2018 from www.alliancemagazine.org.

Body, A. \& Breeze, B. (2016), What are unpopular causes and how can they achieve fundraising success? International Journal of Nonprofit and Voluntary Sector Marketing, 21, $57-70$.

Breiman, L. (2001), Random forests, Machine Learning, 45 (1), 5-32.

Brockman, J., D’Arcy, C. \& Edwards, L. (1979), Facts or artifacts: Changing public attitudes toward the mentally ill, Social Science and Medicine Part A: Medical Psychology and Medical Sociology, 13, 673-682.

Brown, S. \& Taylor, K. (2015), Charity behaviour and the Big 5 Personality traits: Evidence from UK panel data, Sheffield Economic Research Series, Sheffield, Sheffield University.

CAF (2018), UK Giving 2018: An Overview of Charity Giving in the UK, West Malling, Kent, Charities Aid Foundation. 
Charities Commission (2018), Register of Charities, London, Charities Commission.

Charity Watch (2019), Charity Ratings: Criteria and Methodology, Chicago, Charity Watch.

Cialdini, R., Demaine, L., Sagarin, B., Barrett, D., Rhoads, K. \& Winter, P. (2006),

Managing social norms for persuasive impact, Social Influence, 1 (1), 3-15,

Corrigan, P. (2000), Mental disability stigma as social attribution: Implications for research methods and attitude change, Clinical Psychology: Science and Practice, 7 (1), 48-67.

Corrigan, P., Morris, S., Michaels, P., Rafacz, J. \& Rusch, N. (2012), Challenging the public stigma of mental illness: A meta-analysis of outcome studies, Psychiatric Services, 63 (10), 963-973.

Corrigan, P., River, L., Lundin, R., Penn, D., Uphoff-Wasowski, K., Campion, J., Mathisen, J., Gagnon, C., Bergman, M., Goldstein, H. \& Kubiak, M. (2001), Three strategies for changing attributions about severe mental illness, Schizophrenia Bulletin, 27 (2), 187-195.

Corrigan, P. \& Shapiro, J. (2010), Measuring the impact of programmes that challenge the public stigma of mental illness, Clinical Psychology Review, 30 (8), 907-922.

Corrigan, P., Watson, A., Warpinski, G. \& Gracia, G. (2004), Stigmatising attitudes about mental illness and allocation of resources to mental health services, Community Health Journal, 40 (4), 297-307.

Corrigan, P., Watson, A., Warpinski, G. \& Gracia, G. (2004a), Implications of educating the public on mental illness, violence and stigma, Psychiatric Services, 55 (5), 577-580.

Croson, R., Handy, F. \& Shang, J. (2009), Keeping up with the Joneses: The relationship of perceived descriptive social norms, social information, and charitable giving, Nonprofit Management and Leadership, 19 (4), 294-311. 
Dahl, D. (2018), Shock charity campaigns: Building our understanding on their effectiveness, Recherche et Applications en Marketing, 33 (1), 88-91.

Davies, S.C. (2013), Chief Medical Officer's Summary. In: N. Metha (Ed), Annual Report of the Chief Medical Officer 2013, Public Mental disability

Priorities: Investing in the Evidence, London, Department of Health, pp.11-19, https://assets.publishing.service.gov.uk.

Diamantopoulos, A., Sarstedt, M., Fuchs, C., Wilczynski, P. \& Kaiser, S. (2012), Journal of the Academy of Marketing Science, 40 (3), 434-449.

Davey, G. (2013), Mental illness and stigma, Psychology Today, 20 August 2013, pp.1-5, accessed on 2 October 2018 from www.psychologytoday.com.

Davis, M. (1983), Measuring individual differences in empathy: Evidence for a multidimensional approach, Journal of Personality and Social Psychology, 44, 113-126.

Drollinger, T. (2010), A theoretical examination of giving and volunteering utilizing resource exchange theory, Journal of Nonprofit and Public Sector Marketing, 22, 55-66.

Drolet, A. \& Morrison, D. (2001), Do we really need multiple-item measures in service research? Journal of Service Research, 3 (3), 196-204.

DWP (Department of Work and Pensions) (2018), Family Resources Survey 2016/17, London, Department of Work and Pensions, accessed on 19 October 2018 from www.gov.uk.org.

Ewalds-Kvist, B., Hogberg, T. \& Lutzen, K. (2012), Impact of gender and age on attitudes towards mental illness in Sweden, Nordic Journal of Psychiatry, 67 (5), 360-368. 
Goffman, E. (1963), Stigma: Notes on the Management of Spoiled Identity, Englewood Cliffs NJ, Prentice-Hall.

Greenwald, A., McGhee, D. \& Schwartz, J. (1998), Measuring implicit differences in individual cognition: The Implicit Association Test, Journal of Personality and Social Psychology, 74, 14641480.

Gureje, O., Olley, B., Olusola, E. \& Kola, L. (2006), Do beliefs about causation influence attitudes to mental illness? World Psychiatry, 5 (2), 104-107.

Hazzard, A. (1983), Children's experience with, knowledge of, and attitude toward disabled persons, Journal of Special Education, 17 (2), 131-139.

Heider, F. (1958), The Psychology of Interpersonal Relations, New York, Wiley.

Henderson, C. \& Thornicroft, G. (2009), Stigma and discrimination in mental illness: Time to change, The Lancet, 373 (9679), 6-12.

Hibbert, S. \& Horne, S. (1996), Giving to charity: Questioning the donor decision process, Journal of Consumer Marketing, 13 (2), 4-13.

Hibbert, S., Smith, A., Davies, A. \& Ireland, F. (2007), Guilt appeals, persuasion, knowledge and charity giving, Psychology and Marketing, 24 (8), 723-742.

Hiday, V. (2006), Putting community risk in perspective: A look at correlations, causes and controls, International Journal of Law and Psychiatry, 29, 316-331.

Ho, T. (1995), Random decision forests, Proceedings of the 3rd International Conference on Document Analysis and Recognition, Montreal, QC, pp. 278-282.

Kirkwood, A. \& Stamm, B. (2006), A social marketing approach to challenging stigma, Professional Psychology: Research and Practice, 37 (5), 472-476. 
Larsen, R. (1984), Theory and measurement of affect intensity as an individual difference characteristic, Dissertation Abstracts International, 85, 22973 (University Microfilms No. 8422112).

Larsen, R. (2009), Affect intensity. In M. Leary \& R. Hoyle (Eds.), Handbook of Individual Differences in Social Behaviour (pp. 241-254), New York, The Guilford Press.

MacQuillan, I., Sargeant, A. \& Shang, J. (2016), Relationship Fundraising: It's Time to Rethink How You Relate to Your Donors, Plymouth: Pursuant Intelligent Fundraising.

Macrae, C.N., Bodenhausen, G.V., Milne \& Wheeler, V. (1996) On resisting the temptation for simplification: Counter intentional effects of stereotype suppression on social memory, Social Cognition, 14,1-20.

McGinty, E., Goldman, H., Pescosolido, B. \& Barry, C. (2015), Portraying mental illness and drug addiction as treatable health conditions: Effects of a randomised experiment on stigma and discrimination, Social Science and Medicine, 126, 73-85.

Mainardes, E., Laurett, R., Degasperi, N. \& Lasso, S. (2017), External motivators for donation of money and/or goods: External motivators that encourage the donation of money or goods by individuals, International Journal of Nonprofit and Voluntary Sector Marketing, $22(2)$, e1568.

MIND (2013), Types of Mental Health Problem, London, MIND.

MIND (2015), Time to Change: Attitudes to Mental Illness 2014 Research Report, London, MIND.

Moore, D. (1995), Affect intensity and empathic emotions: An individual difference measure of advertising response, Journal of Marketing Communications, 1, 71-89. 
Neumayr, M. \& Handy, F. (2017), Charitable giving: What influences donors' choices among different causes, Voluntas, in press website.

NHS (National Health Service) (2018), Health and Care of People with Learning Disabilities 2016 to 2017, London, NHS Digital, accessed on 9 October 2018 from https//digital.nhs.uk/data-and-information.

NPT (National Philanthropic Trust) (2018), Charitable Giving Statistics in the United Kingdom (online), accessed on $6^{\mathrm{h}}$ November 2018 from http://www.npt-uk.org/philanthropicresources/uk-charitable-giving-statistics.

Oakes, O. (2017), Marketers warned against using mental disability stereotypes at Halloween, Campaign, 26 October 2017, accessed on 19 October 2018 from www.campaignlive.co.uk.

OECD (2010), Mental Health, Disability and Work, Paris, Organisation for Economic Development and Cooperation, accessed on 14 November 2018 from www.oecd.org/els/45008308.pdf.

Park, C. \& Lessig, V. (1981), Familiarity and its impact on consumer decision biases and heuristics, Journal of Consumer Research, 8 (3), 223-230.

Penn, D. \& Couture, S. (2002), Strategies for reducing stigma towards persons with mental illness, World Psychiatry, 1 (1), 20-21.

Pescosolido, B., Monahan, J., Link, B., Stueve, A. \& Kikuzawa, S. (1999), The public's view of the competence, dangerousness, and need for legal coercion of persons with mental disability problems, American Journal of Public Health, 89, 1339-1345.

Piper, G. \& Schnepf, S. (2008), Gender differences in charitable giving in Great Britain, Voluntas, 19 (2), 103-124. 
Ranganathan, S. \& Henley, W. (2008), Determinants of charitable donation intention: A structural equation model, International Journal of Nonprofit and Voluntary Sector Marketing, 13, 1-11.

Ray, J. (1984), The reliability of short social desirability scales, Journal of Social Psychology, 123, 133-134.

Reynolds, W. (1982), Development of reliable and valid short forms of the Marlowe-Crowne social desirability scale, Journal of Clinical Psychology, 38, 119-125.

Rochlen, A. \& Hayer, B. (2005), Marketing mental disability to men: Theoretical and practical considerations, Journal of Clinical Psychology, 61 (6), 675-684.

Rushton, J. (1984), The altruistic personality: Evidence from laboratory, naturalistic and selfreport perspectives, in E. Staub, D. Bar-Tal, J. Karylowski \& J. Reykowski (Eds), Development and Maintenance of Prosocial Behaviour: Critical Issues in Social Justice, London, Plenum Press, pp. 271-290.

Rushton, J., Chrisjohn, R. \& Fekken, G. (1981), The altruistic personality and the self-report altruism scale, Personality and Individual Differences, 2, 293-302.

Sampogna, G., Bakolis, I., Evans-Lacko, S., Robinson, E., Thornicroft, G. \& Henderson, C. (2017), The impact of social marketing campaigns on reducing mental disability stigma: Results from the 2009-2014 Time to Change programme, European Psychiatry, 40, 116-122. Sanghera, B. (2016), Charity giving and lay morality: Understanding sympathy, moral evaluations and social positions, Sociological Review, 64 (2), 294-311.

Sargeant, A. (1999), Charitable giving: Towards a model of donor behaviour, Journal of Marketing Management, 15, 215-238. 
Sargeant, A. (2014), A retrospective - Charitable giving: Towards a model of donor behaviour, Social Business, 4 (4), 293-323.

Sargeant, A. \& Woodliffe, L. (2007), Gift giving: An interdisciplinary perspective, International Journal of Nonprofit and Voluntary Sector Marketing, 12 (4), 275-307.

Schwartz, S. (1977), Normative influences on altruism. In L. Berkowitz (Ed), Advances in Experimental Social Psychology, 10, 221-279, New York, Academic Press.

Shaffer, D. \& Graziano, W. (1983), Effects of positive and negative moods on helping tasks having pleasant or unpleasant consequences, Motivation and Emotion, 7, 269-78.

Shang, J., Reed, A. \& Croson, R. (2008), Identity congruency effects on donations, Journal of Marketing Research, 45 (3), 351-361.

Sirgy, M. \& Su, C. (2000), Destination image, self-congruence, and travel behaviour: Toward an integrative mode, Journal of Travel Research, 38, 340-352.

Sirgy, M., Johar, J. \& Claiborne, C. (1992), Self-concept motivation as mediator between product user self-image congruence and attitude/intention, Developments in Marketing Science, 19, 402-406.

Smith, J. \& McSweeney, A. (2007), Charitable giving: The effectiveness of a revised Theory of Planned Behaviour model in predicting donating intentions and donating behaviour, Journal of Community and Applied Social Psychology, 17, 363-386.

Stride, S. (2006), An investigation into the values dimension of branding: Implications for the charity sector, International Journal of Nonprofit and Voluntary Sector Marketing, 11 (2), $115-124$.

Stuart, H. (2006), Media portrayal of mental illness and its treatments, CNS Drugs, 20 (2), 99106. 
Stuart, H. (2008) Fighting the stigma caused by mental disorders: Past perspectives, present activities, and future directions, World Psychiatry, 7 (3), 185-188.

Thornicroft, G., Rose, D., \& Mehta, N. (2010), Discrimination against people with mental illness: What can psychiatrists do? Advances in Psychiatric Treatment, 16 (1), 53-59.

Wahl, O. (1995), Media Madness: Public Images of Mental Illness, New Brunswick NJ, Rutgers University Press.

Weiner, B., Perry, R. \& Magnusson, J. (1988), An attributional analysis of reactions to stigma, Journal of Personality and Social Psychology, 55 (5), 738-748.

Wesley Schultz, P., Nolan, J., Cialdini, R., Goldstein, N. \& Griskevicius, V. (2007), The constructive, destructive, and reconstructive power of social norms, Psychological Science, $18(5), 429-434$.

Westerhof, G. \& Keyes, C. (2010), Mental illness and mental disability: The two continua model across the lifespan, Journal of Adult Development, 17, 110-119.

Wheat, K., Brohan, E. Henderson, C. \& Thornicroft, G. (2010), Mental illness and the workplace: Conceal or reveal? Journal of the Royal Society of Medicine, 103 (3), 83-86.

Wiepking, P. (2010), Democrats support international relief and the upper class donates to art: How opportunity, incentives and confidence affect donations to different types of charitable organisations, Social Science Research, 39, 1073-1087.

Wilson, R. (1960), Personality patterns, source attractiveness, and conformity, Journal of Personality, 28 (2), 186-199. 
Wong, M., Poole, C. \& Agius, R. (2015), Attribution of mental illness to work: A Delphi study, Occupational Medicine, 65 (5), 391-397. 